\title{
On the Chemical Properties of the Z-Granules
}

\author{
II. Hydrolysis Test \\ By
}

\section{Masabumi Yamasaki \\ (山崎 正文)}

\author{
(From the Department of Anatomy, Tohoku \\ University, Sendai)
}

(Received for Publication, December 20, 1952)

Imprints of rabbit bone marrow fixed in susa solution were incubated in $1 / 10 \mathrm{~N} \mathrm{HCl}$ for some duration at $57^{\circ} \mathrm{C}$, washed in the water and then stained with the aqueous solution of thionin $(0.2 \%)$ and sodium acetate $(5 \%) .^{11}$ The Z-granules ${ }^{1 / 2)}$ characteristic to the granulocyte series (which are stained metachromatically yellow, reddish yellow to brown with the dye when processed without prior hydrolysis) lost their metachromasia almost completely by 40 minutes incubation and "remained as stained blue violet. At the same time it was noticed that the chromatin substance, especially in the erythroblast series, becomes partly to show brown metachromasia which was, however, lost when hydrolysed in advance.

On the other hand, we became aware that the hydrolysed desoxyribonucleic acid (DNA) reveals similar metachromasia. $0.1 \mathrm{~g}$ sodium salt of thymo-DNA was dissolved in $16 \mathrm{cc}$. of $1 / 10 \mathrm{~N} \mathrm{HCl}$ and heated in the boiling water for 3 hours. On addition of a small amount of the thionin-sodium acetate solution to a drop of the hydrolysed DNA solution on an objectglass, there precipitated immediately DNA granules. The specimen was dried and observed under oil immersion. All granules were found metachromatically stained reddish brown to brown.

\section{References}

1) Yamasaki, M. and Oikawa, T., Tohoku J. Exp. Med., this volume, p. 8.

2) Yamasaki, M., Shin Ketsuekigaku-Josetsu (Introduction to New Hematological Conception), Tokyo, 1951. 